\title{
Performance and Some Intestinal Functions of Broilers Fed Diets with Different Inclusion Levels of Sunflower Meal and Supplemented or Not with Enzymes
}

http://dx.doi.org/10.1590/1516-635x170125-30

\section{-Author(s)}

Horvatovic MPI

Glamocic D'

Zikic D'

Hadnadjev TD"

Faculty of Agriculture, University of Novi Sad, Republic of Serbia

" Institute of Food Technology, Novi Sad, Republic of Serbia

\section{Mail Address}

Corresponding author e-mail address Horvatovic MP

PhD Miroslava Polovinski Horvatovic, Faculty of Agriculture, University of Novi Sad, Republic of Serbia e-mail: miroslava.polovinski@yahoo.com

\section{nKeywords}

Carcass characteristics, enzyme activity, performance, viscosity.

\section{ABSTRACT}

Enzyme supplementation of diets enhances broiler performance by improving some of the basic production parameters such as average feed intake, feed conversion ratio, or average weight gain. The enzyme NSPase is commonly used in broiler diets containing high levels of viscous cereals such as barley, oat, wheat, or sorghum. The use of NSPase in diets with different levels of sunflower meal has been not been extensively explored. The experiment was carried out to evaluate the effects of the inclusion of sunflower meal levels in grower and finisher broiler diets supplemented or not with enzymes (cellulase, $\beta$-glucanase, and xylanase) on broiler performance, intestinal function, and carcass traits. A completely randomized experimental design, with $3 * 2$ factorial arrangement with five replicates, was applied (1200 Ross 308 broilers). Sunflower meal inclusion and enzyme supplementation started in grower phase. Broiler performance significantly improved in grower phase (weight gain and feed conversion ratio) by enzyme supplementation, while the effect of sunflower meal was evident in finisher phase, when it significantly reduced weight gain. Sunflower meal increased ileal viscosity, and the interaction between diet and enzyme supplementation was statistically significant. Maltase activity was reduced with sunflower meal dietary inclusion, while enzyme supplementation had no effect either on maltase or sucrase activity. There were no any effects of sunflower meal inclusion with or without enzyme supplementation on carcass characteristics. It can be concluded that high inclusion of sunflower meal in broiler diets may impair broiler performance, but this may be overcome by enzyme supplementation. The effect of enzyme supplementation more evident in the grower phase than in the finisher phase.

\section{INTRODUCTION}

Conventional broiler production is based on corn as a source of energy and soybean meal as a source of protein. Sunflower meal is byproduct of the oil industry and, in the Serbian market, it usually contains 33\% crude protein. It may be a good protein source for broiler diets, although its use may be limited by its low lysine and high fiber contents (Sredanovic et al., 2005). The use of sunflower meal made from dehulled seeds significantly improves the quality of the meal and reduces its percentage of fiber (Levic et al., 1998). However, this process makes production more expensive and diminishes the competitiveness of sunflower meal as an alternative protein source.

Previous studies investigating the effects of the use of sunflower meal as a replacement for soybean meal show inconsistent results. The inclusion of sunflower meal resulted in worse broiler performance in some studies (Abdelrahman et al., 2007; Peric et al., 2010), whereas 
in others, the inclusion of sunflower meal up to $20 \%$ (El-Sherif et al., 1997; Tavernari et al., 2008), or at even higher levels (Rama Rao et al., 2006; Mushtaq et al., 2009) did not have any effects on average body weight or weight gain.

One of the first studies on the use of exogenous enzymes as a supplement of animal diets with the purpose of improving dietary nutrition value was performed in the 1940s (Hastings, 1946). Research on this subject achieved its full extension in the 1980s and 1990s in a broad area of biotechnology (Bhat, 2000).

Enzymes that act on non-starch polysaccharides are mainly used in diets based on wheat, barley, or in some cases, corn for its proven performance improvement of monogastric animals (Bedford, 2000).

The first studies with broiler feeds containing high NSP levels, such as barley, wheat or sorghum, reported poor broiler performance and high gut viscosity. There are limited data on the influence of the dietary inclusion of sunflower meal on broiler gut viscosity. Brazilian research studies showed that 15\% inclusion of sunflower meal in the diet caused a statistically significant increase in viscosity (Araújo et al., 2011). However, the inclusion of sunflower meal up to $35 \%$ in broiler diets did not increase viscosity either in the jejunum or in the ileum. The addition of an exogenous enzyme also had no effects (Kocher et al., 2000).

The activity of two important disaccharidases (maltase and sucrase) is influenced by nutrition (Shakouri et al., 2008; Yang et al., 2008; Zdunczyk et al., 2009). In some studies, the addition of exogenous enzymes that enhance nutrient digestibility by reducing viscosity or increasing nutrient availability in the gastrointestinal tract increased activity of maltase or sucrase or both (Fan et al., 2008; He et al., 2010), while in other studies, the effect of addition of exogenous enzyme did not cause any changes in the activities of maltase or sucrase (Shakouri et al., 2008; Yang et al., 2008).

\section{MATERIAL AND METHODS}

\section{Birds and experimental treatments}

The study was conducted in floor pens in an environmentally controlled poultry house, on the experimental farm of the School of Agriculture in Novi Sad, Republic of Serbia. A total of 1200 day-old Ross $308 \AA$ broilers were distributed in six groups with five replicates each, with 40 (as hatched) birds per pen. Birds were fed ad libitum.

The control diet did not include sunflower meal (SFM). In the first treatment, birds were fed diets with sunflower meal inclusion at $6 \%$ in the grower and $10 \%$ in the finisher phases, respectively, and the second treatment, diets contained sunflower meal (SFM) at $8 \%$ in the grower and $16 \%$ in the finisher periods, respectively. Both the treatment and the control diets were supplemented or not with an enzyme blend (cellulase, $\beta$-glucanase, and xylanase) at $0.01 \%$ in both stages.

Bird body weight and feed intake were weekly monitored.

This experiment was conducted in accordance with the guide of EU directive for the protection of animals used for scientific purposes.

This study was the part of the technology project $N^{\circ} 31033$, which was funded and approved by the appropriate committees of the Republic of Serbia, and registered under n. 401-00-9/2011-01 in January 25, 2011.

\section{Viscosity}

At the end of the experiment (day 42), four birds per replicate were randomly selected and sacrificed. Euthanasia was performed according to the standard procedure used in processing plants. Birds were immediately dissected to obtain intestinal digesta and gut (jejunum and ileum) samples. The collected digesta samples (approximately $2 \mathrm{~g}$ ) were centrifuged at 6000 rpm for $10 \mathrm{~min}$. The obtained supernatant $(0.5 \mathrm{ml})$ was used to determine viscosity. A HAAKE Mars rheometer (Thermo Scientific, Karlsruhe, Germany) was used to perform rheological measurements using C35/2 cone and plate measuring geometry (diameter: $35 \mathrm{~mm}$, cone angle: $2^{\circ}$ ). Samples were allowed to rest for 5 min after loading. The flow curves were obtained by recording shear stress at shear rates from 0 to $500 \mathrm{~s}-1$ in $180 \mathrm{~s}$, at $25 \pm 0.1^{\circ} \mathrm{C}$. All the examined samples exhibited Newtonian flow behavior and thus were characterized by a single coefficient of viscosity.

\section{Enzyme assay}

The samples of the jejunum and the ileum were obtained immediately after evisceration, weighed, labeled, and stored in liquid nitrogen at $-80{ }^{\circ} \mathrm{C}$ until analyses. After thawing and homogenization of the samples, disaccharidase activity was determined according to the method of Dahlqvist (1984). Shortly, the amount of the released glucose was measured spectrophotometrically (UV PG Instruments T80) at $505 \mathrm{~nm}$, and enzyme activity was expressed as unit per minute per gram of protein. One unit of disaccharidase activity hydrolyzed $1 \mu \mathrm{mol}$ of disaccharide/min at $39^{\circ} \mathrm{C}$. Protein content was determined by the method of biuret. 
Table 1 - Composition of the experimental diets.

\begin{tabular}{|c|c|c|c|c|c|c|}
\hline \multirow[b]{3}{*}{ Ingredients } & \multicolumn{6}{|c|}{ Treatment } \\
\hline & \multicolumn{2}{|c|}{ Control } & \multicolumn{2}{|c|}{1} & \multicolumn{2}{|c|}{ II } \\
\hline & grower & finisher & grower & finisher & grower & finisher \\
\hline Corn & 56.09 & 62.40 & 52.80 & 56.89 & 51.91 & 53.47 \\
\hline Soybean oil & 0 & 0 & 0 & 2 & 0 & 3.24 \\
\hline Soybean meal & 21.56 & 17.07 & 13.09 & 10.61 & 10.22 & 6.77 \\
\hline Full-fat soybeans & 17.62 & 16.00 & 23.35 & 16.01 & 25.00 & 16.00 \\
\hline Sunflower meal & 0 & 0 & 6 & 10 & 8 & 16 \\
\hline L-lysine HCL & 0.12 & 0.12 & 0.18 & 0.22 & 0.30 & 0.28 \\
\hline DL-Methionine & 0.26 & 0.22 & 0.24 & 0.20 & 0.24 & 0.19 \\
\hline Limestone & 1.54 & 1.38 & 1.53 & 1.25 & 1.52 & 1.23 \\
\hline Monocalcium phosphate & 1.38 & 1.45 & 1.38 & 1.48 & 1.39 & 1.49 \\
\hline Salt & 0.43 & 0.36 & 0.43 & 0.34 & 0.42 & 0.33 \\
\hline Premix & 1.00 & 1.00 & 1.00 & 1.00 & 1.00 & 1.00 \\
\hline \multicolumn{7}{|l|}{ Calculated composition } \\
\hline Crude protein,\% & 21.00 & 19.00 & 21.00 & 19.00 & 21.00 & 19.00 \\
\hline $\mathrm{ME}, \mathrm{MJ} / \mathrm{kg}$ & 12.60 & 12.80 & 12.60 & 12.80 & 12.60 & 12.80 \\
\hline Lysine, \% & 1.24 & 1.09 & 1.24 & 1.09 & 1.24 & 1.09 \\
\hline Methionine and cystine, $\%$ & 0.95 & 0.86 & 0.95 & 0.86 & 0.95 & 0.86 \\
\hline $\mathrm{Ca}, \%$ & 0.95 & 0.95 & 0.95 & 0.85 & 0.95 & 0.85 \\
\hline P (available), \% & 0.45 & 0.42 & 0.45 & 0.42 & 0.45 & 0.42 \\
\hline
\end{tabular}

\section{Carcass traits}

At the end of feeding trial, two birds (with the average body weight of the pen) per pen, totaling twelve birds per replicate, were sacrificed and eviscerated. Carcass, breast, thigh and drumstick, and abdominal fat weights were recorded and expressed as a percentage of live weight.

\section{Data analysis}

Data were analyzed by two-way analysis of variance using StatSoft software (STATISTICA 8, 2009) to determine the effects of enzyme addition, diet type, and the interaction between these two factors. The results were considered significant when $p<0.05$. Enzyme (maltase, sucrase) activity data were logarithmically transformed prior to the analysis of variance.

\section{RESULTS}

\section{Growth performance}

Performance response of the broilers fed diets with different sunflower meal levels and with or without enzyme supplementation during the grower and finisher phases are presented in Table 2. The effects of enzyme supplementation on weight gain were evident in the grower phase. The inclusion of sunflower meal at 6 and $8 \%$ in grower diet had no effect on growth performance, but at $10 \%$ and $16 \%$ in finisher diet, weight gain was significantly affected. Weight gain statistically improved with dietary enzyme supplementation during the entire experimental period. Neither sunflower meal nor enzyme addition had any effect on feed intake ( $g /$ day).

\section{Enzyme activity and gut viscosity}

The results of digestive enzyme activities and gut viscosity are summarized in Table 3. Diet statistically reduced maltase activity ( $p=0.0162$ ), but not sucrose activity. The effect of region was statistically significant for maltase and sucrose $(p<0.001 ; p=0.0005)$.

The high level of sunflower meal inclusion (16\%) increased gut viscosity, particularly in the ileum. The effects of diet and of the interaction between diet and enzyme on gut viscosity was significant $(p=0.001)$.

The effects of sunflower meal inclusion and enzyme supplementation on carcass traits (dressing percentage, and breast, thigh and drumstick and abdominal fat yields) are shown in Table 4. There was no significant effect of sunflower meal or enzyme supplementation on the evaluated parameters.

\section{DISCUSSION}

Dietary sunflower meal inclusion reduced weight gain in the finisher phase, but not in the grower period. This can be explained by the relatively small amount of sunflower meal in diet (6\% and $8 \%$ ) in grower phase. However, some authors have reported the influence of the inclusion of sunflower meal at $5 \%$ and $8 \%$ in grower diets on broiler average body weight (Peric et al., 2010). 
Table 2 - Effects of different dietary inclusion levels of sunflower meal and of enzyme supplementation on feed intake, body weight gain, and feed conversion ratio of broilers.

\begin{tabular}{|c|c|c|c|c|c|c|c|c|c|c|}
\hline \multirow{2}{*}{$\begin{array}{l}\frac{0}{0} \\
\frac{0}{\alpha} \\
\end{array}$} & \multicolumn{4}{|c|}{ Treatment } & \multicolumn{2}{|c|}{ enzyme } & \multirow{2}{*}{ SEM } & \multicolumn{3}{|c|}{ Probability } \\
\hline & days & control & I & $\|$ & - & + & & Diet & enzyme & $D * E$ \\
\hline & \multicolumn{10}{|c|}{ Feed intake (g/bird) } \\
\hline \multirow{2}{*}{$\begin{array}{l}\bar{o} \\
\text { ò } \\
\bar{\sigma}\end{array}$} & $14-21$ & 578 & 592 & 571 & 584 & 577 & 8.37 & 0.608 & 0.725 & 0.952 \\
\hline & $22-28$ & 911 & 897 & 910 & 897 & 910 & 10.22 & 0.660 & 0.554 & 0.882 \\
\hline \multirow{4}{*}{ 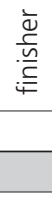 } & $29-35$ & 1200 & 1180 & 1216 & 1182 & 1214 & 12.24 & 0.510 & 0.231 & 0.700 \\
\hline & $36-42$ & 1279 & 1274 & 1283 & 1269 & 1289 & 13.88 & 0.986 & 0.507 & 0.377 \\
\hline & $14-42$ & 3970 & 3939 & 3980 & 3934 & 3992 & 29.89 & 0.835 & 0.326 & 0.691 \\
\hline & \multicolumn{10}{|c|}{ Weight gain (g/bird) } \\
\hline \multirow{2}{*}{$\begin{array}{l}\bar{d} \\
\overline{0} \\
\overline{0}\end{array}$} & $14-21$ & 377 & 411 & 384 & 380 & 402 & 12.26 & 0.539 & 0.412 & 0.979 \\
\hline & $22-28$ & 604 & 568 & 592 & 573 & 603 & 8.63 & 0.225 & 0.049 & 0.943 \\
\hline \multirow{4}{*}{$\frac{\bar{d}}{\stackrel{\underline{\underline{M}}}{E}}$} & $29-35$ & 585 & 576 & 571 & 584 & 571 & 9.82 & 0.759 & 0.456 & 0.005 \\
\hline & $36-42$ & 583 & 505 & 552 & 535 & 558 & 5.50 & 0.012 & 0.227 & 0.667 \\
\hline & $14-42$ & 2149 & 2060 & 2099 & 2071 & 2134 & 16.87 & 0.062 & 0.039 & 0.290 \\
\hline & \multicolumn{10}{|c|}{ Feed conversion ratio } \\
\hline \multirow{2}{*}{$\begin{array}{l}\bar{o} \\
\sum_{0}^{\circ} \\
\overline{0}\end{array}$} & $14-21$ & 1.492 & 1.433 & 1.511 & 1.517 & 1.441 & 0.03 & 0.551 & 0.226 & 0.929 \\
\hline & $22-28$ & 1.512 & 1.544 & 1.587 & 1.582 & 1.514 & 0.02 & 0.267 & 0.049 & 0.650 \\
\hline \multirow{3}{*}{$\frac{\bar{\Phi}}{\stackrel{\underline{\underline{W}}}{\underline{E}}}$} & $29-35$ & 2.047 & 2.036 & 2.061 & 2.006 & 2.090 & 0.03 & 0.933 & 0.159 & 0.026 \\
\hline & $36-42$ & 2.309 & 2.561 & 2.376 & 2.443 & 2.386 & 0.04 & 0.027 & 0.437 & 0.781 \\
\hline & $14-42$ & 1.850 & 1.913 & 1.896 & 1.901 & 1.871 & 0.02 & 0.271 & 0.362 & 0.562 \\
\hline
\end{tabular}

The effect of the use of exogenous enzymes on feed conversion rate and growth rate in this trial was evident in the grower phase, but not in the finisher phase. Results on the use of exogenous enzyme in broiler diets are contradictory. Some researchers undoubtedly point out that the increase in body weight gain is due to the effect of the use of carbohydratases (Mathlouthi et al., 2002; Francesch \& Geraert, 2009; Hajati, 2010). Other authors reported an increase in diet digestibility, but not in broiler performance (Marsman et al., 1997; Kocher et al., 2000; Preston et al., 2000), whereas some did not observe any effect (Aftab, 2009).

Sunflower meal had no effect on feed conversion ratio. Literature studies reported that high levels of sunflower meal inclusion in grower and finisher broiler diets (up to $20 \%$ ) had no effect on feed conversion ratio (El-Sherif et al., 1997; Furlan et al., 2001; Tavernari et al., 2008; Aftab, 2009; Peric et al., 2010). Moreover, some researchers found that the highest level sunflower meal inclusion (20\%) in the diet improved feed conversion ratio which was explained by the fact that the oil inclusion level was increased in order to supply birds' energy needs (Tavernari et al., 2008).

In this study feed conversion ratio improved with the supplementation of exogenous enzymes to the grower diets, indicating that digestibility was enhanced. Some studies reported stronger effects of enzyme addition on nutrition digestibility and feed conversion ratio in younger broilers (up to three weeks of age) (Shakouri et al., 2008). The digestive tract of young broilers has not reached its maximum capacity, which may explain those effects.

Sunflower meal significantly increased digesta viscosity in the ileum, while enzyme supplementation decreased digesta viscosity only in the treatments with sunflower meal inclusion. Viscosity increased from the proximal to the distal digestive tract. This is probably due to the effect of the concentration of compounds that produce viscosity during the process of digestion or perhaps due to the increased hydration of those compounds (Boros et al., 1998). The main effect of enzyme supplementation on viscosity was not observed. However, the interaction between enzyme and diet was statistically significant, which indicates that the enzymes reduced digesta viscosity only when the diet with the high sunflower meal inclusion was fed, and therefore, when the diet contained higher NSP levels. The supplementation of the enzyme glucanase in barley-based diets fed to chickens of two different ages (21-day-old broilers and 1-year-old roosters) 
Table 3 - Effects of different dietary inclusion levels of sunflower meal (SFM), of intestinal segment (jejunum or ileum), and of enzyme supplementation on sucrose and maltase activities (U/g proteins) and viscosity ( $\left.\mathrm{mPa}^{*} \mathrm{~s}\right)$.

\begin{tabular}{|c|c|c|c|}
\hline & $\begin{array}{c}\text { Sucrase activity, } \\
\mathrm{U} / \mathrm{g}\end{array}$ & $\begin{array}{c}\text { Maltase activity, } \\
\mathrm{U} / \mathrm{g}\end{array}$ & $\begin{array}{c}\text { Viscosity, } \\
\text { mPa*s }\end{array}$ \\
\hline \multicolumn{4}{|l|}{ Jejunum } \\
\hline control & 21.66 & 138.10 & 2.395 \\
\hline Treatment I & 16.84 & 137.36 & 3.059 \\
\hline Treatment II & 15.86 & 106.06 & 2.518 \\
\hline \multicolumn{4}{|l|}{ enzyme } \\
\hline- & 19.03 & 139.62 & 2.92 \\
\hline+ & 17.46 & 117.79 & 2.461 \\
\hline \multicolumn{4}{|l|}{ Ileum } \\
\hline control & 15.22 & 78.71 & 2.336 \\
\hline Treatment I & 9.95 & 67.41 & 2.513 \\
\hline Treatment II & 7.26 & 49.28 & 7.214 \\
\hline \multicolumn{4}{|l|}{ Enzyme } \\
\hline- & 6.28 & 68.51 & 4.89 \\
\hline+ & 15.35 & 67.76 & 3.407 \\
\hline SEM & 1.49 & 7.04 & 0.072 \\
\hline \multicolumn{4}{|l|}{ Probability } \\
\hline Diet & 0.151 & 0.0162 & 0.001 \\
\hline Enzyme & 0.227 & 0.292 & 0.135 \\
\hline Region & 0.0005 & 0.0000 & 0.018 \\
\hline Diet*enzyme & 0.954 & 0.404 & 0.010 \\
\hline Diet*region & 0.781 & 0.796 & 0.000 \\
\hline Region*enzyme & 0.141 & 0.589 & 0.592 \\
\hline$D * E * R$ & 0.535 & 0.252 & 0.341 \\
\hline
\end{tabular}

Enzyme activity was expressed as unite per minute per gram of protein.

reduced digesta viscosity in both periods. However, diet digestibility significantly increased in younger birds, suggesting that the effect of enzyme supplementation was not only due to viscosity reduction (Almirall et al., 1995).

Although enzyme supplementation reduced digesta viscosity in the finisher phase in the present study, it did not improve broiler performance, especially weight gain and feed conversion ratio. The improvement was evident, but not statistically significant.
The dietary supplementation of exogenous enzyme enhanced diet digestibility possibly because it promoted an increase in the activity of digestive enzymes by increasing the availability of substrates. When adding exogenous amylase and protease to broiler diets, researchers reported higher activity of pancreatic and intestinal enzymes measured in 14- and 42-d-old broilers, especially in the younger birds (14 days) (Pinheiro et al., 2004). Diets based on barley, maize, sorghum, and wheat significantly affected the activity of intestinal enzymes, while enzyme supplementation did not (Shakouri et al., 2008). According to another study (Zdunczyk et al., 2009), maltase and sucrase activity was reduced when turkeys were fed diets with high fiber levels. The lower intestinal enzyme activity due to the effect of diet observed in the present study may be explained by the higher fiber level the diets with high sunflower meal content of the finisher diets.

Enzyme activity was reduced from the proximal to distal part of intestine. These results are in agreement with the previous studies (Cavides-Vidal et al., 2000; Uni et al., 1999).

Carcass and parts traits determine the purchase decision of chicken meat consumers. Neither sunflower meal nor exogenous enzymes had any effect on carcass traits in this trial. These results are in agreement with reports from other authors, who also did not find any effects of sunflower meal or exogenous enzymes on carcass traits (Tavernari et al, 2008; Mushtaq et al., 2009). In the work of Seleh et al. (2005), the addition of cellulase to a broiler diet based on corn and soybean meal significantly reduced abdominal fat. The authors concluded that cellulase affected fat metabolism in an unknown way. However, some studies suggest that enzyme supplementation may improve carcass yield (Omojola \& Adesehinwa, 2007). The use of NSPase in diets with a high sunflower meal inclusion levels

Table 4 - Effects of different dietary inclusion levels of sunflower meal and of enzyme supplementation on carcass traits of broilers.

\begin{tabular}{|c|c|c|c|c|c|c|c|c|}
\hline \multirow{2}{*}{$\begin{array}{l}\text { Treatment } \\
\text { control }\end{array}$} & \multirow[b]{2}{*}{1} & \multicolumn{4}{|c|}{ enzyme } & \multicolumn{3}{|c|}{ Probability } \\
\hline & & $\|$ & - & + & SEM & Diet & Enzyme & $D * E$ \\
\hline \multicolumn{9}{|c|}{ Dressing percentage (\%) } \\
\hline 83.64 & 82.54 & 82.66 & 82.70 & 83.19 & 0.3 & 0.275 & 0.418 & 0.577 \\
\hline \multicolumn{9}{|l|}{ Breast (\%) } \\
\hline 27.60 & 27.11 & 26.40 & 26.74 & 27.32 & 0.3 & 0.187 & 0.275 & 0.674 \\
\hline \multicolumn{9}{|c|}{ Thigh and drumstick (\%) } \\
\hline 21.41 & 21.40 & 22.20 & 21.51 & 21.83 & 0.2 & 0.119 & 0.358 & 0.911 \\
\hline \multicolumn{9}{|c|}{ Abdominal fat (\%) } \\
\hline 1.61 & 1.60 & 1.57 & 1.64 & 1.55 & 0.07 & 0.984 & 0.612 & 0.998 \\
\hline
\end{tabular}

Carcass, breast, thigh and drumstick, and abdominal fat weights were recorded and expressed as a percentage of live weight. 
Horvatovic MP, Glamocic D, Zikic D, Hadnadjev TD

\section{Performance and Some Intestinal Functions of Broilers Fed Diets with Different Inclusion Levels of Sunflower Meal and Supplemented or Not with Enzymes}

He J, Liu C, Fu C, Li J. Effects of extrusion and supplementation of exogenous enzymes to diets containing Chinese storage brown rice on the carbohydrase activity in the digestive tract of piglets. Journal of Animal Physiology \& Animal Nutrition 2010;94(2):146-153.

Khan SH, Sardar R, Siddique B. Influence of enzymes on performance of broilers fed sunflower-corn based diets. Pakistan Veterinary Journal 2006;26(3):109-114.

Kocher A, Choct M, Porter MD, Broz J. The effects of enzyme addition to broiler diets containing high levels of canola and sunflower meal. Poultry Science 2000; 79:163-173.

Levic J, Radoicic, D, Sredanovic S, Levic Lj. Technological procedures for enhancing the production of high protein content sunflower meal. In: Koseoglu SS, Rhee kc, Wilson RF, editor. Advances in oils and fats, antioxidants and oilseed by-products. American Oil Chemists' Society Press; 1998. p.104-107.

Marsman GJ, Gruppen H, van der Poel AF, Kwakkel RP, Verstegen MW, Voragen AG. The effect of thermal processing and enzyme treatments of soybean meal on growth performance, ileal nutrient digestibilities, and chyme characteristics in broiler chicks. Poultry Science 1997;76:864-872.

Mathlouthi N, Mallet S, Saulnier L, Quemner B, Larbier M. Effects of xylanase and -glucanase addition on performance, nutrient digestibility, and physico-chemical conditions in the small intestine contents and caecal microflora of broiler chickens fed a wheat and barley-based diet. Animal Research 2002;51:395-406.

Mushtaq T, Sarwar M, Ahmad G, Mirza MA, Ahmad T, Noreen U, Mushtaq MMH, Kamran Z. Influence of sunflower meal based diets supplemented with exogenous enzyme and digestibile lysine on performance, digestibility and carcass response of broiler chikens. Animal Feed Science and Technology;149:275-286. 2009.

Omojola AB, Adesehinwa AOK. Performance and Carcass Characteristics of Broiler Chickens Fed Diets Supplemented with Graded Levels of Roxazyme G. International Journal of Poultry Science;6(5):335-339. 2007.

Peric L, Milic D, Bjedov S. The effect of sunflower meal on growth performance of broiler chicks. Proceedings of the 13th European Poultry Conference; 2010; Tours. France.

Pinheiro DF, Cruz VC, Sartori JR, Vicentini Paulino MLM. Effect of early feed restriction and enzyme supplementation on digestive enzyme activities in broilers. Poultry Science 2004;83:1544-1550.

Preston GM, McCracken KJ, McAllister A. Effect of diet form and enzyme supplementation on growth, efficiency and energy utilization of wheatbased diets for broilers. British Poultry Science 2000;41:324-331.

Rama Rao SV, Raju MVLN, Panda AK, Redely MR. Sunflower seed meal as a substitute for soybean meal in commercial broiler chicken diets. British Poultry Science 2006;47:592-598.

Saleh F, Ohtsuka A, Hayashi K. Effect of dietary enzymes on the ileal digestibility and abdominal fat content in broilers. Animal Science Journal 2005;76:475-478.

Shakouri MD, lji PA, Mikkelsen LL, Cowieson AJ. Intestinal function and gut microflora of broiler chickens as influenced by cereal grains and microbial enzyme supplementation. Journal of Animal Physiology and Animal Nutrition 2008;93:647-658.

Sredanovic S, Levic J, Djuragic O. Enzyme enhancement of the nutritional value of sunflower meal. Biotechnology in Animal Husbandry 2005;21(5-6-2):197-202.

Uni Z, Noy Y, Sklan D. Posthatch development of small intestinal function in the poult. Poultry Science 1999;78:215-222.

Yang Y, lji PA, Kocher A, Mikkelsen LL, Choct M. Effects of xylanase on growth and gut development of broiler chickens given a wheat-based diet. Asian-Australasian Journal of Animal Sciences 2008;21(11):16591664. 2008.

Zdunczyk Z, Jankowski J, Juskiewicz J, Lecewicz J, Slominski B. Application of soybean meal, soy protein concentrate and isolate differing in $\alpha$-galactosides content to low- and high-fibre diets in growing turkeys. Journal of Animal Physiology and Animal Nutrition 2009;85:1-10. 